\title{
Diel patterns of vertical distribution in larvae of southern bluefin Thunnus maccoyii, and other tuna in the East Indian Ocean
}

\author{
Tim L. O. Davis, Greg P. Jenkins, Jock W. Young \\ CSIRO Division of Fisheries, Marine Laboratories, GPO Box 1538, Hobart, Tasmania 7001, Australia
}

\begin{abstract}
Vertical distributions of larvae of 3 tuna species were investigated in the East Indian Ocean. In the presence of a strong pycnocline, the entire depth range of tuna larvae could be covered by sampling the mixed layer by both day and night. A small proportion of tuna larvae were found below the mixed layer when the pycnocline was weak. Thunnus maccoyii and $T$. alalunga larvae moved into the surface layers during the day. Katsuwonus pelamis, however, moved into deeper water during the day. All species of tuna were more evenly dispersed in the mixed layer at night. Greater numbers and larger larvae of $T$ maccoyii and $K$. pelamis were captured at night, indicating marked differences in net avoidance between day and night. No evidence of increased avoidance during the day was found in $T$ alalunga. The relative abundance of $T$ maccoyil larvae could be predicted from surface tows; however, the relationship between surface and oblique tows showed regional and diel variability. To reduce bias and increase precision, estimates of tuna larvae abundance should be based on oblique tows made at night from the surface to just below the mixed layer.
\end{abstract}

\section{INTRODUCTION}

In the open ocean, most larval fish occur in the mixed layer and the upper part of the thermocline (Ahlstrom 1959). Within this region, many larvae show some diel change in depth distribution (Kendall \& Naplin 1981). It has been suggested that these diel vertical movements are related to the vertical distribution of prey (Seliverstov 1974, Hunter \& Sanchez 1976), avoidance of predators (Brewer et al. 1984), regulation of dispersal (Fortier \& Leggett 1982, Brewer \& Kleppel 1986), and conservation of energy (Hunter \& Sanchez 1976). Thus knowledge of vertical distribution is critical to understanding the early life history of marine fishes.

Apart from ecological considerations, knowledge of the vertical distribution of ichthyoplankton is critical for the correct assessment of their abundance. Sampling only part of the depth range of larvae will produce underestimates of abundance. Sampling far below the depth range is wasteful of time and resources. It also reduces sample size and the resulting estimates of abundance will be more affected by the spatial distribution patterns of the larvae (Andrew \& Mapstone 1987). As tuna larvae usually occur in low densities (Wade 1951, Strasburg 1960, Klawe 1963, Richards
1969, Richards \& Simmons 1971, Conand \& Richards 1982), sampling the correct depth range is critical.

Previous studies suggest that tuna larvae are more concentrated towards the surface. Using simultaneous tows with non-closing nets at different depths, Matsumoto (1958) found that tuna larvae (mainly Katsuwonus pelamis and some Thunnus albacares) in the Central Pacific were concentrated in the surface layers, and suggested that they might migrate vertically during the day to a depth of less than $50 \mathrm{~m}$. Strasburg (1960), using both opening and closing nets at different depths, concluded that about $80 \%$ of tuna larvae were above $60 \mathrm{~m}$, with practically none below $130 \mathrm{~m}$. He also suggested they made a diel vertical migration, as larger numbers of larvae were caught in surface waters at night than during the day, a situation also observed by Wade (1951) in Philippine waters. From closing net hauls, Klawe (1963) found that T. albacares and Auxis thazard occurred only above the thermocline in the eastern Pacific Ocean. Therefore there is some evidence that tuna larvae occur mainly near the surface and are probably limited to the depth of the mixed layer.

The primary aim of this research was to determine the optimal sampling procedure (in terms of vertical 
distribution) for estimating tuna larvae abundance. Our first objective was to determine the minimum sampling depth. required to maximize catches and still cover the entire depth range of tuna larvae. As the depth of the mixed layer can vary markedly $(10$ to $70 \mathrm{~m}$ ) on the Thunnus maccoyii spawning grounds during the spawning season (Yukinawa \& Miyabe 1984, Yukinawa \& Koido 1985), our strategy was to determine whether the distribution of tuna larvae extended below this mixed layer rather than to determine whether they were limited to any fixed depth. Our second objective was to examine the effect of depth distribution patterns on catch rates in surface and oblique tows. While these objectives were directed at assessing the effect of vertical distribution on estimating tuna larvae abundance, the data also provided information on diel vertical movements of tuna larvae.

\section{MATERIALS AND METHODS}

Description of nets. We used 2 types of nets: an Ocean Instruments $70 \mathrm{~cm}$ opening/closing bongo net and a $70 \mathrm{~cm}$ diameter ring net. The bongo net, rigged with a $22 \mathrm{~kg}$ Scripps cable depressor (Gehringer \& Aron 1968), was modified to take an electronically operated opening/closing system consisting of a Yeokal Submersible Data Logger (SDL) with standard depth and temperature sensors. The data logger also received signals from a General Oceanics electronic flowmeter mounted inside the net and had additional circuitry to drive solenoids that opened and closed the nets. Signals to and from the net were multiplexed to the ship via an armored cable and displayed on deck using the graphic interface of an Apple Macintosh computer. When fired, each solenoid released its collar bridle allowing either the canvas doors covering the mouth of the net or the net itself to pull free of the net frame in the conventional manner. The net was deployed with the mouth cover fitted and this was released at the required depth and the net fished through the selected depth stratum. At the end of the tow the net was closed by releasing it from the bongo frame and was held closed by a short choke line surrounding the net collar. This system enabled a discrete depth sample to be taken without contamination from other depth strata.

The ring net had a $70 \mathrm{~cm}$ diameter aluminium collar equivalent to one side of an Ocean Instruments $70 \mathrm{~cm}$ bongo net. A 2-wire bridle mounted laterally on the collar, back from the mouth, enabled the net to be towed with little obstruction from the bridle. A $22 \mathrm{~kg}$ Scripps depressor was connected to the net by a second bridle mounted in the same way as the first. An electronic pressure sensor mounted on the bridle enabled the net to be guided by real-time depth data when deployed in oblique tows from the stern. When deployed at the surface, the ring net was towed from a boom on the port side amidships, clear of the wake of the vessel. It was towed ca $0.5 \mathrm{~m}$ under the surface. oscillating between 0 and $2 \mathrm{~m}$.

Both the bongo and ring nets were fitted with blue cylindrical-conical nets made of plain weave Estal monofilament with a mesh aperture of $0.5 \mathrm{~mm}$ and open area ratio of 5:1 (Tranter \& Smith 1968). All nets were fitted with a mechanical General Oceanics flowmeter, calibrated before sampling and mounted within the aluminium collar. All nets were towed at speeds of 1.0 to $1.3 \mathrm{~m} \mathrm{~s}^{-1}$

Sampling strategy. Sampling was carried out from FRV 'Soela' on 2 cruises in January/February and November/December 1987 on the Thunnus maccoyii spawning grounds in the eastern Indian Ocean. These grounds have been defined by Japanese surveys (Nishikawa et al. 1985). Sampling sites were selected by making trial plankton tows until significant numbers of $T$. maccoyii larvae were located. Once larvae were located the water parcel was tracked with a drogued buoy. On the first cruise, 2 satellite-tracked buoys (Cresswell et al. 1978) with parachute drogues set at $20 \mathrm{~m}$ depth were deployed. On the second cruise, a strobe-lit buoy drogued with a $4.5 \times 1.0 \mathrm{~m}$ Draper LCD (Dahlen 1986) tethered at $10 \mathrm{~m}$ depth was used. It was necessary to tether the LCD at a shallower depth than the parachute to drogue the same depth strata because it hangs vertically. Experience from the first cruise also indicated that the larvae might be better tracked if the drogue was placed higher in the mixed layer.

The first objective to determine whether tuna larvae occurred below the mixed layer was examined on each cruise (Series $A$ and $B$ in Fig. 1). Samples in Series A were taken on 16 and 17 January 1987 between $21: 00$ and $12: 00 \mathrm{~h}$ local time near satellitetracked buoy no. 6127 . The buoy was at $16^{\circ} 29^{\prime} \mathrm{S}$, $115^{\circ} 22^{\prime} \mathrm{E}$ and drifting NE when sampling started. Samples in Series B were taken between 13:00 and 19:00 h on 10 December 1987 alongside a drogued buoy that started at $15^{\circ} 35^{\prime} \mathrm{S}, 115^{\circ} 54^{\prime} \mathrm{E}$ and drifted NW. The opening/closing bongo was deployed in single oblique tows. It was either opened a short distance below the mixed layer and fished to the surface, or opened at twice the depth of the mixed layer and closed before it reached the mixed layer. A surface tow with the $70 \mathrm{~cm}$ ring net was made concurrently with each oblique tow. The depth of the mixed layer was already known. from CTD profiles taken at the drogue buoy. The positioning, opening and closing of the net were guided by temperature and depth readouts from the SDL mounted on the net. Oblique tows in Series A lasted for $20 \mathrm{~min}$, and for $10 \mathrm{~min}$ in Series 
B. Surface tows were always of $10 \mathrm{~min}$ duration. A mechanical flowmeter was mounted behind the choking point on the opening/closing net during Series A. The volume filtered while the net was open was calculated directly from these readings. A mechanical flowmeter was not fitted to the opening/closing bongo during Series B, so readings from the flowmeter mounted in the surface net were used to estimate volumes filtered by the oblique tow. This was done after adjustment for warp retrieval and tow trajectory. As plankton volumes in surface and oblique tows were always low, clogging of the nets would not have affected the filtration efficiency of either type of tow.

The second objective was to examine the effect of depth distribution patterns on catch rates in surface and oblique tows, and provide information on diel vertical near-surface movements. Two $70 \mathrm{~cm}$ ring nets were deployed concurrently, one as a surface tow for $10 \mathrm{~min}$ and the other as an oblique tow for 20 min. At Site 1 the double oblique tow was fished from the surface down through the upper layer of the pycnocline to a depth of $50 \mathrm{~m}$ and back again. At Site 2 the net was only fished down to $40 \mathrm{~m}$. Daytime sampling was done from $08: 30$ to $16: 00 \mathrm{~h}$ local time and night-time sampling from 20:00 to $04: 30 \mathrm{~h}$, to avoid transitional dawn and dusk periods. At Site 1, 10 day and 10 night tows were made on 21 and 22 January 1987 at stations randomly placed in a $10 \mathrm{~km}$ radius circle relative to satellite-tracked buoy no. 6127 , which was at $16^{\circ} 6^{\prime} \mathrm{S}$, $115^{\circ} 45^{\prime} \mathrm{E}$ when sampling began (Fig. 1). At Site 2, 22 day and 22 night tows were made at random positions

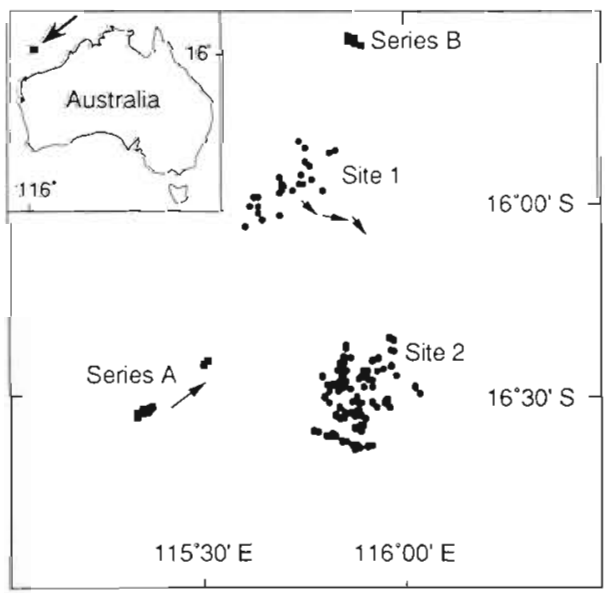

Fig. 1. Ichthyoplankton stations in the Indian Ocean northwest of Australia. Series A was taken on 16 to 17 January and Series B on 10 December 1987 to determine whether tuna larvae occurred below the mixed layer To investigate diel vertical distribution of tuna larvae within the mixed layer, Site 1 stations were occupied on 21 to 22 January and Site 2 stations on 29 January to 2 February 1987 at random positions in relation to a drogued buoy. Arrows indicate the direction of drift of satellite-tracked buoy no. 6127 during sampling at Series A and Site 1 in a $20 \mathrm{~km}$ radius circle relative to satellite-tracked buoy no. 6128, which remained almost stationary at $16^{\circ} 32^{\prime} \mathrm{S}, 115^{\circ} 53^{\prime}$ E between 29 January and 2 February 1987.

Treatment of samples. All samples were preserved in $95 \%$ ethanol, which was replaced within $12 \mathrm{~h}$ of initial preservation. Tuna larvae were sorted from plankton samples in a rotable sorting ring under a dissecting microscope with dark-field illumination, and identified to species using, in the main, the criteria of Nishikawa (1985): When there were more than 200 tuna larvae in a sample, a random subsample of 200 were identified to species and the remainder assigned to species proportionately. For each bongo tow, samples were sorted from both nets and pooled. Ichthyoplankton and station data for both cruises are presented in detail in Davis \& Clementson (1989). Standard length (tip of the snout to tip of the notochord, or the hypural crease in postflexion larvae) was measured under a dissecting microscope with an ocular micrometer. Measurements were made on Thunnus maccoyii larvae collected in oblique tows from Site 2 . When there were more than 20 larvae in a sample, a random subsample of 20 larvae was measured and weighted by the sample total. Because the numbers of the other species of tuna larvae were much lower, all $T$. alalunga and Katsuwonus pelamis larvae from oblique tows from Sites 1 and 2 were measured.

Data analysis. Catch rates of larvae from surface and oblique tows were expressed as numbers per $1000 \mathrm{~m}^{3}$ strained. Larval abundance was expressed as numbers per $100 \mathrm{~m}^{2}$ sea surface, calculated from the volume filtered and depth traversed by the net (depth traversed by surface tows $=2 \mathrm{~m}$; oblique tows at Site $1=50 \mathrm{~m}$, at Site $2=40 \mathrm{~m})$. Because $\log (\mathrm{x}+1)$ transformed data did not depart seriously from the assumption of homogeneity of variance (Cochran's test; Site $1, \mathrm{C}_{(4,9)}=0.53, \mathrm{p}<0.05$; Site $\left.2, C_{\{4,21\}}=0.30, p>0.05\right)$, parametric procedures were used to test for statistical differences between surface and oblique catch rates (numbers $1000 \mathrm{~m}^{-3}$ ) of Thunnus maccoyii at Sites 1 and 2 . While the variances of Site 1 data were just significantly different at the 0.05 level (the critical value for $C_{(4,9)}=0.50$ ), $F$ tests are robust with respect to moderate departures from homogeneity of variance (Winer 1971). Differences between surface and oblique catch rates of $T$. maccoyii larvae by day and night at Sites 1 and 2 were tested by 2 -factor repeated measure ANOVA with tow type as the within-subjects factor. Nonparametric 2-factor analysis of variance (NPANOVA) (Zar 1984) was used on T. alalunga and Katsuwonus pelamis catch-rate data (numbers $1000 \mathrm{~m}^{-3}$ ) because of the high proportion of zero values (usually greater than $20 \%$ ). The data from both sites were combined to compensate for the lower numbers of $T$. alalunga and $K$. pelamiscaught compared to T. maccoyii. 
To determine whether surface tows adequately describe the abundance of Thunnus maccoyii larvae, regressions of oblique/surface catch rates were computed on untransformed numbers per $1000 \mathrm{~m}^{3}$ for each site and day-night combination, and differences between regressions were tested by ANCOVA. The ratio of larvae present in surface tows to that present in oblique tows (surface-oblique ratio) and the catch ratio between day and night determined from oblique tows were calculated from weighted geometric mean abundance (numbers $100 \mathrm{~m}^{-2}$ ). The significance of differences in surface-oblique ratios for $T$. maccoyii between day and night were determined using t-tests after first computing the variance of the ratios (Kendall \& Stuart 1958). The significance of differences in abundance between day and night was determined by t-test for $T$. maccoyii and the normal approximation to the Mann-Whitney test (MW), corrected for ties, for $T$. alalunga and Katsuwonus pelamis. Differences in the lengths of larvae caught during the day and night were examined using the Kolmogorov-Smirnov (KS) 2sample test on cumulative length frequency distributions of $0.5 \mathrm{~mm}$ (Standard Length; SL) categories (Sokal \& Rohlf 1981).

\section{RESULTS}

\section{Physical environment}

Sampling on both cruises was carried out in the southern part of the North Australia Basin which had a bottom depth of ca $5000 \mathrm{~m}$. There was little difference between the maximum and minimum temperatures and salinities recorded at the surface on both cruises. The range was 34.6 to $35.0 \%$ and 27.0 to $28.6^{\circ} \mathrm{C}$. On 16 January 1987, when Series A sampling began, the start of the pycnocline was well defined at $27 \mathrm{~m}$ by a $1.4^{\circ} \mathrm{C}$ drop in temperature and a salinity change of $0.11 \%$ over $6 \mathrm{~m}$ (Fig. 2a). The bottom of the mixed layer was relatively shallow and ranged from 16 to $22 \mathrm{~m}$, as measured by the net-mounted SDL during each tow. A few hours after Series A tows were completed, a cyclone developed in the region; 3 d later the mixed layer extended to $48 \mathrm{ml}$ (Fig. 2b). The mixed layer extended to this depth while we were sampling for larval tuna at Site 1 during 21 to 22 January 1987 (Fig. 1). At Site 2 the bottom of the mixed layer ranged from 32 to $42 \mathrm{~m}$ (mostly less than $40 \mathrm{~m}$ ) during sampling between 29 January and 2 February 1987 (Fig. 1). On the cruise in December 1987 the pycnocline was poorly developed, changing by less than $0.3^{\circ} \mathrm{C}$ and $0.04 \%$ salinity in $5 \mathrm{~m}$ (Fig. $2 \mathrm{c}$ ). It was not always possible to judge the bottom of the mixed layer using the net-mounted SDL during Series B tows.

\section{Depth distribution}

Tuna larvae were caught in all Series A surface tows on 16 and 17 January 1987, with the greatest numbers in the last few stations sampled (Table 1). Variation in the number of tuna larvae at each station was not important because only the presence or absence of larvae was required. Oblique tows above the pycnocline included the mixed layer (bottom at 16 to $22 \mathrm{~m}$ ) plus part of the pycnocline. All these oblique tows except at Stn 1, caught larvae, although at lower
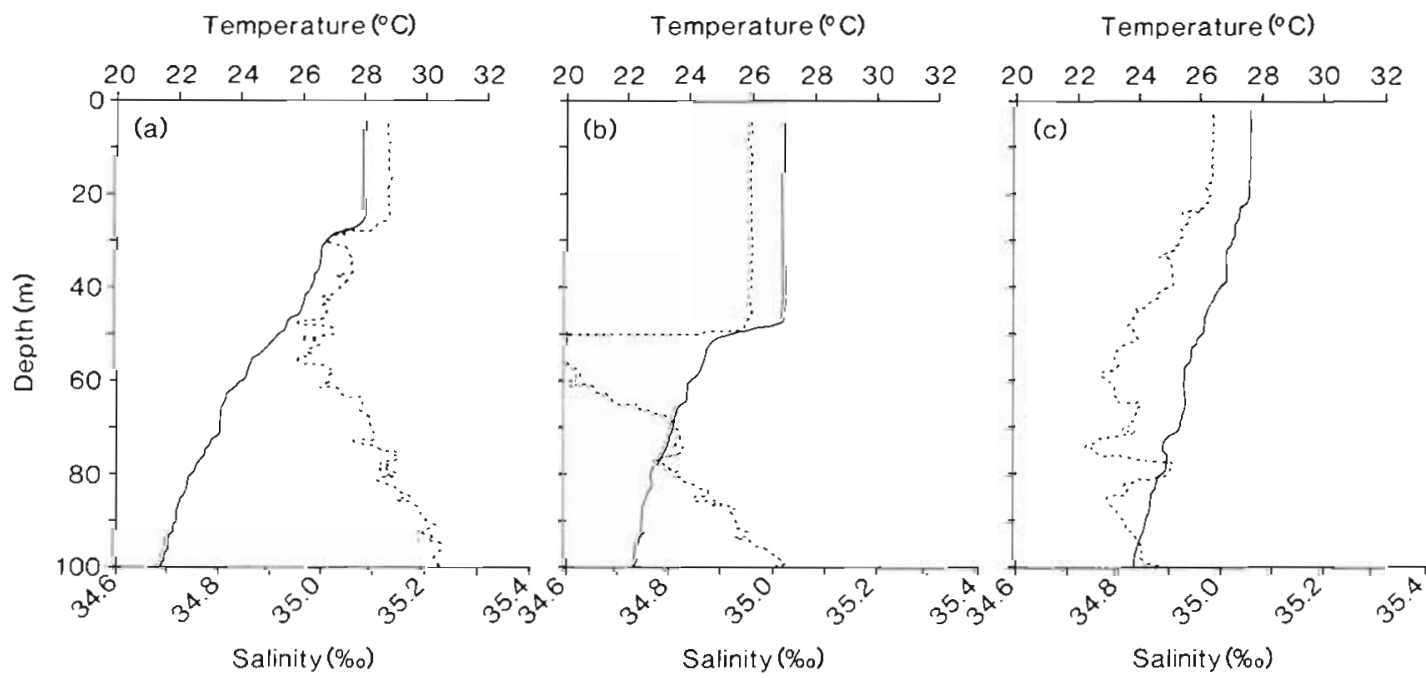

Fig. 2. Salinity (---) and temperature (-) profiles to $100 \mathrm{~m}$ depth from CTD casts: (a) at buoy no. 6127 on 16 January 1987 prior to Series A stations and cyclone Connie; (b) at buoy no. 6127 on 20 January 1987 after cyclone Connie; (c) at Series B stations on 10 December 1987 
Table 1. Numbers of tuna larvae and larvae of other fish species $1000 \mathrm{~m}^{-3}$ caught at different depths in tows from Series A on 16 to 17 January 1987. -: no sample taken

\begin{tabular}{|c|c|c|c|c|c|c|c|c|}
\hline \multirow[t]{3}{*}{ Stn } & \multirow{3}{*}{$\begin{array}{l}\text { Pycnocline } \\
\text { depth (m) }\end{array}$} & \multicolumn{2}{|c|}{ Surface tows } & \multicolumn{4}{|c|}{ Oblique tows } & \multirow{3}{*}{$\begin{array}{c}\text { Tow } \\
\text { depth }(\mathrm{m})\end{array}$} \\
\hline & & \multirow[b]{2}{*}{ Tuna } & \multirow[b]{2}{*}{ Others } & \multicolumn{2}{|c|}{$\begin{array}{l}\text { Including } \\
\text { mixed layer }\end{array}$} & \multicolumn{2}{|c|}{$\begin{array}{c}\text { Without } \\
\text { mixed layer }\end{array}$} & \\
\hline & & & & Tuna & Others & Tuna & Others & \\
\hline 1 & 16 & 32.2 & 19.3 & 0 & 22.8 & - & - & $35-0$ \\
\hline 3 & 22 & 44.1 & 58.8 & 16.2 & 44.0 & - & - & $34-0$ \\
\hline 8 & 20 & 155.0 & 118.1 & 34.1 & 155.5 & - & - & $37-0$ \\
\hline 2 & 18 & 22.4 & 39.1 & 6.3 & 482.9 & 0 & 230.2 & $79-33,79-0^{a}$ \\
\hline 4 & 22 & 6.6 & 26.6 & - & - & 0 & 190.4 & $70-33$ \\
\hline 5 & 20 & 50.1 & 28.6 & - & - & 0 & 311.2 & $72-34$ \\
\hline 6 & 20 & 10.2 & 23.7 & - & - & 0 & 281.7 & $72-34$ \\
\hline 7 & 20 & 143.6 & 71.8 & - & - & 0 & 74.8 & $78-34$ \\
\hline
\end{tabular}

densities than the corresponding surface tows. Tuna larvae were absent from all oblique tows below the mixed layer, although they did contain other species of fish larvae. Stn 2 was a tow below the mixed layer. One bongo net failed to close and continued to fish to the surface. This side contained tuna larvae, whereas the side that closed below the mixed layer did not. Thunnus maccoyii was the most abundant tuna species identified in these samples ( $74 \%$ ), followed by Katsuwonus pelamis (17\%) and $T$. alalunga (9\%).

During December, tuna larvae were present in all surface tows taken in Series B, although numbers were low at 2 stations (Table 2). Tuna larvae were also present in 3 of the 6 tows below the mixed layer. In the first 2 of these tows (Stns 2 and 3), the number of tuna larvae was small relative to the number in the corresponding surface tows ( 3 to $7 \%$ ). In the third tow (Stn 4), the number of tuna larvae below the mixed layer was about half that of the surface tow, which had relatively few larvae. Thunnus alalunga was the most abundant tuna species in this series of tows (53\%), followed by $T$. maccoyii (35\%) and Katsuwonus pelamis (12\%). The tuna species caught below the mixed layer were $K$. pelamis $(83 \%)$ and T. maccoyii $(17 \%)$.

\section{Distribution within the mixed layer}

Site 1 was ca $50 \mathrm{~km} \mathrm{NW}$ of Site 2 (Fig. 1). However, buoy no. 6127, which marked the water at Site 1, had drifted to a point $76 \mathrm{~km} \mathrm{NE}$ of Site 2 when sampling began at the latter site on 29 January. A total of 6616 Thunnus maccoyii larvae were obtained in paired surface and oblique tows made at the 64 stations occupied at Sites 1 and 2 . The catch rates of $T$. maccoyii larvae in oblique tows during the day were lower than the catch rates in all other tows at both Site 1 and Site 2 as indicated by the significant interaction between tow depth and day-night (Table 3). There was little difference between surface catch rates during the day and surface and oblique catch rates at night. We compared the variability in catch rates from oblique tows and

Table 2. Numbers of tuna larvae and larvae of other fish species $1000 \mathrm{~m}^{-3}$ caught at different depths in tows from Series $B$ on 10 December 1987, -: no sample taken

\begin{tabular}{|c|c|c|c|c|c|c|c|c|}
\hline \multirow[t]{3}{*}{ Stn } & \multirow{3}{*}{$\begin{array}{l}\text { Pycnocline } \\
\text { depth (m) }\end{array}$} & \multicolumn{2}{|c|}{ Surface tows } & \multicolumn{4}{|c|}{ Oblique tows } & \multirow{3}{*}{$\begin{array}{c}\text { Tow } \\
\text { depth }(\mathrm{m})\end{array}$} \\
\hline & & \multirow[b]{2}{*}{ Tuna } & \multirow[b]{2}{*}{ Others } & \multicolumn{2}{|c|}{$\begin{array}{l}\text { Including } \\
\text { mixed layer }\end{array}$} & \multicolumn{2}{|c|}{$\begin{array}{l}\text { Without } \\
\text { mixed layer }\end{array}$} & \\
\hline & & & & Tuna & Others & Tuna & Others & \\
\hline 1 & 24 & 52.6 & 15.8 & - & - & 0 & 136.8 & $71-35$ \\
\hline 2 & undefined & 102.3 & 37.2 & - & - & 7.0 & 116.2 & $63-36$ \\
\hline 3 & 14 & 114.0 & 95.1 & - & - & 3.8 & 58.9 & $69-35$ \\
\hline 4 & 25 & 7.5 & 63.7 & - & - & 3.7 & 71.2 & $67-35$ \\
\hline 5 & 26 & 47.2 & 137.8 & 22.2 & 196.9 & - & - & $30-0$ \\
\hline 6 & 23 & 23.6 & 129.9 & - & - & 0 & 53.2 & $87-60$ \\
\hline 7 & 23 & 4.5 & 306.3 & - & - & 0 & 94.6 & $60-35$ \\
\hline
\end{tabular}


Table 3. Thunnus maccoyii. Catch rates of larvae in paired surface and oblique tows at Sites 1 and 2 and tests for differences between, and regressions of, surface and oblique catch rates by day and night. Geometric mean and $95 \%$ confidence limits (CL) are expressed as numbers $1000 \mathrm{~m}^{-3}$ with the number of $10 \mathrm{ws}(\mathrm{n})_{i} \cdot \mathrm{p}<0.05, \cdots p<0.01, \cdots p<0.001$

\begin{tabular}{|c|c|c|c|c|c|c|}
\hline & \multicolumn{3}{|c|}{ Site 1} & \multicolumn{3}{|c|}{ Site 2} \\
\hline & Mean & $95 \% \mathrm{CL}$ & $\mathrm{n}$ & Mean & $95 \% \mathrm{CL}$ & $\mathrm{n}$ \\
\hline \multicolumn{7}{|l|}{ Day } \\
\hline Surface tow & 22.3 & $5.8-85.0$ & 10 & 43.3 & $18.4-101.5$ & 22 \\
\hline Oblique tow & 5.6 & $2.9-10.7$ & 10 & 16.6 & $6.8-40.9$ & 22 \\
\hline \multicolumn{7}{|l|}{ Night } \\
\hline Surface tow & 20.2 & $10.6-38.6$ & 10 & 33.3 & $14.2-78.1$ & 22 \\
\hline Oblique tow & 19.8 & $8.5-45.9$ & 10 & 52.3 & $26.8-102.3$ & 22 \\
\hline \multicolumn{7}{|l|}{ ANOVA (F-values) } \\
\hline Depth & & 6.71 & & & 1.25 & \\
\hline Day-night & & 1.01 & & & 0.68 & \\
\hline Depth/day-night & & $6.26^{\circ}$ & & & $10.11 \cdots$ & \\
\hline \multicolumn{7}{|c|}{ Regression oblique/surface } \\
\hline \multicolumn{7}{|c|}{ Day } \\
\hline Constant & & 0.74 & & & 45.98 & \\
\hline Regression coefficient & & 0.12 & & & 0.66 & \\
\hline$r^{2}$ & & 0.77 & & & 0.17 & \\
\hline $\mathrm{F}$ & & $26.2 \cdots$ & & & 4.0 & \\
\hline \multicolumn{7}{|l|}{ Night } \\
\hline Constant & & -10.13 & & & 29.23 & \\
\hline Regression coefficient & & 1.68 & & & 0.86 & \\
\hline$r^{2}$ & & 0.89 & & & 0.83 & \\
\hline$F$ & & $65.1 \cdots$ & & & $98.1 \cdots$ & \\
\hline
\end{tabular}

found no significant difference between day and night at Site 1 (variance ratio test, 1 -tailed, $F=1.4, p>0.5$ ), but at Site 2 the variance of catch rates during the day was significantly larger than that at night $(F=2.21, p<$ 0.05). We examined the relationship between oblique and surface catch rates and found that regressions were significant at both sites at night and at Site 1 during the day, with ca $80 \%$ of the variance explained by the regressions (Table 3 ). The slopes of these 3 regressions were significantly different (ANCOVA, $F=4.59, \mathrm{df}=2$, $\mathrm{p}<0.05$ ). The relationship between surface and oblique tows was not significant at Site 2 during the day.

The relative abundance of Thunnus maccoyii larvae (numbers $100 \mathrm{~m}^{-2}$ ) in paired surface and oblique tows at Sites 1 and 2 is presented in Table 4 . The proportion of T. maccoyii larvae in surface tows (surface-oblique ratio) was significantly higher during the day than at night, indicating that a proportion of $T$ maccoyii larvae move to the surface during the day. The difference in surface-oblique ratios between Sites 1 and 2 was not significant at night (t-test, $\mathrm{p}>0.2$ ) and not quite significant during the day (t-test, $0.05<\mathrm{p}<0.1$ ). The abundance of $T$. maccoyii in 20 min oblique tows was significantly larger at night than during the day, with a catch ratio between day and night of ca 0.28 at both sites (Table 4 ). Although there are several possible causes, we attribute the larger catches of $I$ maccoyii at night to differences in net avoidance between day and night (see 'Discussion'). Greater avoidance during the day is also indicated by the length frequency data for $T$. maccoyii from Site 2 (Fig. 3a). Larval T. maccoyii caught at night were significantly larger than those caught during the day (KS test, $\mathrm{D}=0.208$, $\mathrm{p}<0.001$ ).

During daytime, the catch rates of Thunnus alalunga larvae from surface tows were greater than the rates from oblique tows (Table 5). The former were also greater than either surface or oblique catch rates taken at night. There was a significant interaction between tow depth and day and night (NPANOVA, p <0.001), similar to that found in $T$. maccoyii catch data. However, this result was due to elevated catches in surface tows during the day rather than depressed catches in oblique tows during the day as was the case for $I$ maccoyii. The surface-oblique ratio in $T$. alalunga larvae varied markedly between day and night, changing by 0.6 at both sites combined (Table 6). Thus a large proportion of $T$ alalunga larvae must move to the surface during the day. $T$. alalunga showed no significant difference in abundance in oblique tows between day and night (MW test, $\mathrm{p}>0.5$ ), with a catch ratio between day and night of 0.87 (Table 6). The length-frequency distributions of $T$. alalunga larvae (Fig. 3b) also did not differ between day and night ( $\mathrm{KS}$ test, $\mathrm{D}=0.02, \mathrm{p}>0.95$ ).

The day-night distribution of Katsuwonus pelamis 
Table 4. Thunnus maccoyii. Relative abundance of larvae in paired surface and oblique tows, surface-oblique ratio during the day and night, catch ratio between day and night, and t-test for differences between surface-oblique ratios and abundance day and

night. Geometric mean and $95 \%$ confidence limits $\left(\mathrm{CL}\right.$ ) are expressed as numbers $100 \mathrm{~m}^{-2}$ with the number of tows ( $\mathrm{n}$ )

\begin{tabular}{|c|c|c|c|c|c|c|}
\hline & \multicolumn{3}{|c|}{ Site 1} & \multicolumn{3}{|c|}{ Site 2} \\
\hline & Mean & $95 \% \mathrm{CL}$ & $\mathrm{n}$ & Mean & $95 \% \mathrm{CL}$ & $\mathrm{n}$ \\
\hline \multicolumn{7}{|l|}{ Day } \\
\hline Surface tow & 5.8 & $2.1-16.1$ & 10 & 10.6 & $5.3-21.2$ & 22 \\
\hline Oblique tow & 26.7 & $12.6-56.6$ & 10 & 55.6 & $20.1-154.3$ & 22 \\
\hline \multicolumn{7}{|l|}{ Night } \\
\hline Surface tow & 4.3 & $2.5-7.4$ & 10 & 8.3 & $4.2-16.5$ & 22 \\
\hline Oblique tow & 96.3 & $39.9-232.2$ & 10 & 205.1 & $102.9-408.8$ & 22 \\
\hline \multicolumn{7}{|c|}{ Surface-oblique ratio } \\
\hline Day & 0.29 & $0.16-0.43$ & & 0.19 & $0.08-0.30$ & \\
\hline Night & 0.04 & $0.02-0.07$ & & 0.04 & $0.02-0.06$ & \\
\hline \multicolumn{7}{|c|}{$\mathrm{H}_{0}$ : No difference between day and night } \\
\hline & $t=$ & $1, \mathrm{df}=18, \mathrm{p}$ & & & $80, \mathrm{df}=42, \mathrm{p}$ & \\
\hline \multicolumn{7}{|c|}{$\mathrm{H}_{0}$ : No difference between Sites 1 and 2} \\
\hline Day & $\mathrm{t}=$ & $8, \mathrm{df}=30, \mathrm{p}$ & & & & \\
\hline Night & $t=$ & $0, \mathrm{df}=30, \mathrm{p}$ & & & & \\
\hline \multicolumn{7}{|c|}{ Catch ratio between day and night } \\
\hline Oblique tow & 0.30 & $0.16-0.45$ & & 0.27 & $0.12-0.42$ & \\
\hline \multicolumn{6}{|c|}{$\mathrm{H}_{0}$ : No difference between day and night } & \\
\hline
\end{tabular}
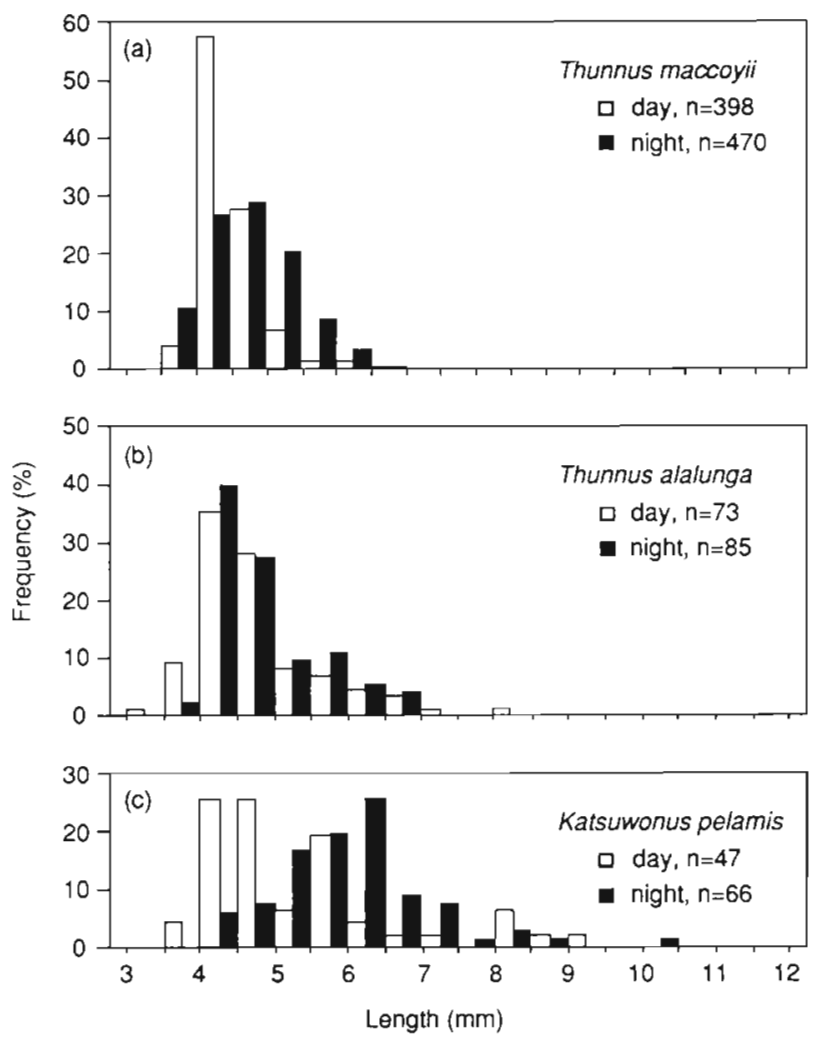

Fig. 3. Length-frequency distributions of larvae caught during the day (open bars) and at night (black bars). (a) Thunnus maccoyiu from Site 2 (numbers refer to subsampled larvae that were measured); (b) $T$ alalunga from Sites 1 and 2; (c) Katsuwonus pelamis from Sites 1 and 2 differed markedly from both Thunnus species in that they were never caught at the surface during the day (Table 5). Catch rates in oblique tows were always greater at night than during the day, and catch rates in oblique tows were always greater than catch rates in surface tows. These differences in catch rates by tow depth and day and night were both highly significant (NPANOVA, $p<0.001$ ). While no $K$. pelamis larvae were present at the surface during the day, the surfaceoblique ratio at night was also negligible (Table 6). The catch ratio between day and night was 0.41 (which is comparable to that observed in $T$. maccoyii), and the abundance of $K$. pelamis larvae in oblique tows was significantly greater at night than during the day (MW test, $\mathrm{p}<0.05)$. While the length-frequency distributions are irregular, $K$. pelamis larvae caught at night were significantly larger (KS test, $\mathrm{D}=0.417, \mathrm{p}<0.001$ ) than those caught during the day (Fig. 3c). Both the differences in catches and length-frequency distributions between day and night indicate that net avoidance by $K$. pelamis larvae was greater during the day than at night.

\section{DISCUSSION}

\section{Depth distribution}

In the presence of a well-defined pycnocline, the entire depth range of tuna larvae would be covered by sampling the mixed layer and the uppermost part of the 
Table 5. Thunnus alalunga and Katsuwonus pelamis. Catch rates of larvae in paired surface and oblique tows from Sites 1 and 2 combined, and tests for differences between surface and oblique catch rates by day and night. Geometric mean and range are expressed as numbers $1000 \mathrm{~m}^{-3}$ with the number of tows $(n) ; \cdots p<0.001$

\begin{tabular}{|c|c|c|c|c|c|c|}
\hline & \multicolumn{3}{|c|}{ Thunnus alalunga } & \multicolumn{3}{|c|}{ Katsuwonus pelamis } \\
\hline & Mean & Range & $\mathrm{n}$ & Mean & Range & $\mathrm{n}$ \\
\hline \multicolumn{7}{|l|}{ Day } \\
\hline Surface tow & 12.3 & $0-129.3$ & 32 & 0 & $0-0$ & 32 \\
\hline Oblique tow & 1.7 & $0-11.1$ & 32 & 0.9 & $0-7.4$ & 32 \\
\hline \multicolumn{7}{|l|}{ Night } \\
\hline Surface tow & 1.4 & $0-16.7$ & 32 & 0.9 & $0-8.6$ & 32 \\
\hline Oblique tow & 2.0 & $0-11.9$ & 32 & 1.8 & $0-8.2$ & 32 \\
\hline \multicolumn{7}{|c|}{ Nonparametric ANOVA (H-values) } \\
\hline Depth & & 5.99 & & & $12.71 \cdots$ & \\
\hline Day-night & & 8.23 & & & $13.10^{\cdots} \cdots$ & \\
\hline Depth/day-night & & $12.83 \cdots$ & & & 0.81 & \\
\hline
\end{tabular}

pycnocline both day and night. The pycnocline appears to act as a physical barrier, as Klawe (1963) suggested, so any diel vertical migration is restricted to the mixed layer. In December the pycnocline was poorly defined, and the slight gradient in temperature and salinity did not appear to limit the vertical distribution of tuna larvae. However, few tuna larvae were found below $35 \mathrm{~m}$. In the absence of a well-defined pycnocline, sampling to ca $35 \mathrm{~m}$ under these circumstances probably would not seriously bias abundance estimates. As most of the larvae caught below the thermocline were Katsuwonus pelamis, any bias might be restricted to this species - and it would be far less than the bias associated with differences in avoidance and vertical distribution between day and night, and small in comparison with other variability associated with ichthyo- plankton sampling. The benefits of sampling to greater depths to ensure coverage of the entire depth range of the tuna larvae would be outweighed by the statistical weakness of the resulting small catch-per-unit volume.

Considerable effort has gone into surveys of the distribution of tuna larvae, particularly southern bluefin tuna, Thunnus maccoyii, in the eastern Indian Ocean (Ueyanagi 1969, Yonemori \& Morita 1978, Yukinawa \& Miyabe 1984. Yukinawa \& Koido 1985, Yukinawa 1987). These surveys have been based on samples obtained with $2 \mathrm{~m}$ ring nets deployed at the surface concurrently with oblique tows to ca $30 \mathrm{~m}$ depth. The data from these surveys were examined to determine whether their standard oblique tows to $30 \mathrm{~m}$ would cover the entire depth range of tuna larvae. The depths of the mixed layer at each ichthyoplankton

Table 6. Thunnus alalunga and Katsuwonus pelamis. Relative abundance of larvae in paired surface and oblique tows from Sites 1 and 2 combined, surface-oblique ratio by day and night, catch ratio between day and night, and Mann-Whitney test for differences in abundance in oblique tows day and night. Geometric mean and range are expressed as numbers $100 \mathrm{~m}^{-2}$ with the numbers of tows $(n)$

\begin{tabular}{|c|c|c|c|c|c|c|}
\hline & \multicolumn{3}{|c|}{ Thunnus alalunga } & \multicolumn{3}{|c|}{ Katsuwonus pelamis } \\
\hline & Mean & Range & $\mathrm{n}$ & Mean & Range & $\mathrm{n}$ \\
\hline \multicolumn{7}{|l|}{ Day } \\
\hline Surface & 3.3 & $0-25.9$ & 32 & 0 & $0-0$ & 32 \\
\hline Entire depth & 5.0 & $0-44.3$ & 32 & 2.5 & $0-29.7$ & 32 \\
\hline \multicolumn{7}{|l|}{ Night } \\
\hline Surface & 0.4 & $0-3.3$ & 32 & 0.3 & $0-1.7$ & 32 \\
\hline Entire depth & 5.7 & $0-59.3$ & 32 & 6.2 & $0-37.5$ & 32 \\
\hline \multicolumn{7}{|c|}{ Suriace-oblique ratio } \\
\hline Day & 0.66 & & & 0.0 & & \\
\hline Night & 0.08 & & & 0.05 & & \\
\hline \multicolumn{7}{|c|}{ Catch ratio between day and night } \\
\hline Oblique tow & 0.87 & & & 0.41 & & \\
\hline \multicolumn{7}{|c|}{$\mathrm{H}_{0}$ : No difference between day and night } \\
\hline & \multicolumn{3}{|c|}{$z=0.637, p>0.5$} & \multicolumn{3}{|c|}{$z=2.152, p<0.05$} \\
\hline
\end{tabular}


station could be determined from reports on 3 cruises. In October to December 1983 the mixed layer was deeper than $30 \mathrm{~m}$ at $39 \%$ of the stations (Yukinawa \& Miyabe 1984), in January to March 1984 at $36 \%$ of the stations (Yukinawa \& Koido 1985) and in January to March 1987 (coincident with this study) at $50 \%$ of the stations (Yukinawa 1987). Thus the entire depth range of the tuna larvae may not have been sampled at a number of these stations. We do not have information on the fine-scale vertical distribution of tuna larvae to determine what proportion of larvae would be missed by tows not penetrating the pycnocline. A number of studies have indicated that the boundary at the top of the pycnocline can be a region of concentration of larvae (Angel 1968, Loeb 1979). If this were the case for tuna larvae, tows that were stopped short of the pycnocline would underestimate abundance.

\section{Diel vertical distribution}

A much greater proportion of larvae of both Thunnus maccoyii and $T$. alalunga were present in the surface samples during the day than at night. Both species showed the same trends, although $T$. alalunga showed the most marked change, with $68 \%$ of the population at the surface during the day and only $8 \%$ there at night. Similar differences between day and night were found in both species during the 1983 survey of this area (Yukinawa \& Miyabe 1984). No difference was found for $T$. maccoyii in the 1984 survey, and $T$. alalunga were only caught in surface tows at night (Yukinawa \& Koido 1985). Similar trends were again found for $T$. maccoyii in the 1987 survey (coincident with this study), while there was little difference in $T$. alalunga (Yukinawa 1987). The variation between these 3 surveys could be due to inter-annual variation. the relatively small numbers of larvae caught, or because sampling during the day and night was widely separated both temporally and spatially. No conclusions can be drawn on the diel depth distribution of $T$. maccoyii or $T$. alalunga from other studies because of the low numbers caught, but similar patterns have also been observed for $T$. albacares and $T$. obesus (Richards \& Simmons 1971). This reverse pattern of vertical distribution, in which fish larvae rise to the surface during the day and descend at night, appears to be more common than once thought. In addition to Thunnus, it has been observed in the larvae of Gadus macrocephalus (Boehlert et al. 1985), Ammodytes personatus (Yamashita et al. 1985) and Brevoortia patronus (Sogard et al. 1987) and postlarval Macrorhamphosus gracilis (Badcock \& Merrett 1976).

The vertical movement of Thunnus maccoyii and $T$. alalunga larvae in this study may be associated with feeding, which only occurs during the day (J. W. Young unpubl.). It is possible the larvae feed mainly in the surface waters, maintaining themselves in the upper layers and passively dropping out of this layer when feeding and associated swimming activity stops. Either the depth range traversed daily by the larvae is small, but sufficient to have a marked impact on catches in surface tows, or a larger-scale diel vertical migration may be occurring. Fine-scale vertically stratified sampling is required to resolve the extent of vertical movement. As yet we cannot determine whether the feeding and food of $T$. maccoyii and $T$. alalunga larvae are restricted to the upper layers because the catches from deeper tows are contaminated by larvae from the surface, nor can we determine whether all or part of the population is involved in this diel migration at some stage during the day.

Katsuwonus pelamis larvae, in contrast to Thunnus maccoyii and $T$. alalunga, did not move to the surface during the day and only a small proportion were at the surface at night. $K$. pelamis showed the same diel pattern of vertical distribution found in other studies of this species (Strasburg 1960, Ueyanagi 1969, Yukinawa \& Miyabe 1984, Yukinawa \& Koido 1985), although the evidence in some studies is not compelling either because few larvae were caught (Matsumoto 1958 , Yukinawa 1987) or because differences in net avoidance between day and night were not resolved (Wade 1951, Richards \& Simmons 1971).

The movement of Katsuwonus pelamis larvae into the surface at night resulted in similar surface-oblique ratios to that of Thunnus maccoyii and $T$. alalunga. This suggests that all 3 species are dispersing in the vertical plane in the same way at night. However, during the day, movement is in opposite directions: T. maccoyii and $T$. alalunga larvae rise to the surface, and the few $K$. pelamis larvae at the surface move deeper. As $K$. pelamis, like both Thunnus species, also feeds only during the day (J. W. Young unpubl.), it must be feeding below the surface. Its diet is quite different to that of $T$. maccoyii and T. alalunga, consisting primarily of appendicularians and fish larvae rather than copepods and cladocerans (Uotani et al. 1981). These differences may be the cause or the effect of feeding in a different depth strata, although alternatively $K$. pelamis larvae may be selecting its prey.

\section{Day and night net avoidance}

We attribute the larger catches of Thunnus maccoyii and Katsuwonus pelamis larvae in oblique tows at night to differences in net avoidance between day and night. Daytime vertical migration to depths below that traversed by the oblique tows could also be an explana- 
tion. However, we demonstrated, from the samples taken in Series A (Table 1), that tuna larvae were found only in the mixed layer both day and night. Series $\mathrm{A}$ and Site 1 samples, though taken $4 \mathrm{~d}$ apart, came from the same water parcel tracked by buoy no. 6127 . Therefore these results indicate that differences in catches are due to greater net avoidance during the day than at night, not to vertical migration below the mixed layer during the day. Site 1 was sampled during the full moon and Site 2 just before the new moon; moon phase did not appear to affect the reported differences in avoidance.

Increased daytime net avoidance by Thunnus maccoyil larvae is also suggested by the reduced proportion of larger larvae in daytime catches. The ability to avoid a net depends on escape speed, which is considered to be a function of the size of the larvae, and reaction distance (Barkley 1972, Murphy \& Clutter 1972). An increase in the reaction distance due to earlier detection of the approach of the net in daylight hours would enable the larger larvae to more effectively avoid the net at this time.

In contrast, Thunnus alalunga did not appear to avoid the net more successfully by day than by night. The consistency of the catch ratios with the lengthfrequency distributions of the day and night catches strongly suggests that there is little or no diel difference in avoidance in $T$. alalunga. However, it is difficult to explain why 2 very similar species $-T$. maccoyii and $T$. alalunga - should be so different in their ability to avoid nets

In most studies, greater catches of tuna larvae are made at night than during the day (Nakamura \& Matsumoto 1965, Yukinawa \& Miyabe 1984, Yukinawa \& Koido 1985); the failure to detect these differences might be attributable to inadequacies in experimental design. Richards \& Simmons (1971) found significant differences between day and night catches at the surface in the lengths of Thunnus albacares, Euthynnus alletteratus and Auxis sp., but not of $T$. obesus or Katsuwonus pelamis. They concluded that the first group of species, but not the second, showed greater net avoidance during the day. However, these data were based on surface tows only, so do not take into account possible size-dependent vertical migration. Similarly, avoidance deduced from differences in surface catches between day and night cannot be separated from the effects of diel vertical migration without reference to catches in oblique tows to appropriate depths (Ahlstrom 1954). Ueyanagi (1969) caught more $K$. pelamis in oblique tows at night than during the day, yet there appeared to be little difference in the lengthfrequency distributions of the day and night catches, although neither difference was tested statistically Yabe et al. (1966) presented length-frequency data for
T. thynnus (presumably from surface and oblique tows combined) that showed marked differences between day and night, which would suggest increased avoidance during the day. However, these data are pooled between years and localities and cannot be compared with catch rates, as the corresponding catch data are not in a suitable form.

\section{Sampling strategy for larval tuna surveys}

Differences in catches between day and night observed in larvae of many fish species (Ahlstrom 1954, 1959. Bridger 1956) indicates that avoidance is a problem common to most methods of ichthyoplankton sampling. However, the evidence for avoidance is conservative, as its extent can only be gauged against other methods of capture (Clutter \& Anraku 1968); in this case sampling at night, which may also be subject to avoidance though to a lesser degree. It is clear that the $70 \mathrm{~cm}$ net catches a limited size range of tuna larvae, even at night. The net rarely catches Thunnus maccoyii larvae longer than $7 \mathrm{~mm}$. However, it is not clear that larger ichthyoplankton nets would necessarily capture a wider size range of larvae. The $70 \mathrm{~cm}$ ring net caught greater numbers of tuna larvae when compared directly with a $2 \mathrm{~m}$ ring net and was at least as efficient at catching the larger larvae (Davis et al. 1989).

Sampling at night, while not eliminating avoidance entirely, does provide the best estimate of larval abundance. During the day tuna larvae migrate vertically, which results in their concentrating at particular depths, which may vary between species. Estimates of larval abundance based on tows taken during the day will be subject to greater error than those made at night when the larvae are more uniformly distributed (because of the difficulty in obtaining even tow profiles that will sample these restricted depths proportionately).

The greatest problems appear to be in under- or oversampling surface waters. It is difficult to control not only the descent rate during the deployment of the net but also its ascent rate as it is retrieved from the water In addition, most oblique tows are deployed from the stern. and it is not clear to what extent the surface water sampled is contaminated by deep water stirred up by the vessel. As both Thunnus maccoyi and $T$. alalunga are concentrated at the surface during the day, sampling at this time will be more variable. The variance in catches of $T$. maccoyii from oblique tows at night was significantly lower than in those made during the day at Site 2. That such a difference was detectable and not obscured by the high variability inherent in sampling highly contagious distributions suggests that the results from daytime sampling are much more variable than from night sampling. Also, the species composition of 
samples taken during the day is more likely to be biased because of the different diel vertical distribution patterns and avoidance levels exhibited by each of the 3 species of tuna larvae at that time.

There was a close relationship between catches of Thunnus maccoyii in paired surface tows and oblique tows except during the day at Site 2. Surface tows, which require much less effort than oblique tows, have been used in some tuna larvae surveys (Wade 1951, Richards \& Simmons 1971, Miller 1979). Under certain conditions, surface tows do provide a reasonable indication of the relative abundance of tuna larvae. However, we observed a very poor relationship between surface and oblique catches of $T$. maccoyii larvae at Site 2 during the day and, even when the relationships were well-defined, the regressions differed significantly between day and night and between sites. It was thus necessary to calibrate surface catches with oblique catches for each set of conditions prior to surveying. Catches were too small to make valid calibrations for larvae of other tuna species. We also demonstrated that species of tuna larvae have different patterns of vertical distribution, which would drastically affect the species composition of catches in surface tows during the day. As it would be impractical to determine by how much daytime catches of rarer tuna species would be biased by specific patterns of diel vertical distribution, as well as differences in avoidance between day and night, surface sampling to determine the distribution and composition of species of tuna larvae would have to be done at night. However, to reduce bias and increase precision, estimates of tuna larvae abundance should be based on double oblique tows at night deployed from the surface to just below the mixed layer.

Acknowledgements. We thank the Master and crew of FRV 'Soela' and CSIRO personnel, particularly D. W. Rimmer and J L. May, who assisted in the field work. We are grateful to $O$. Augustine for sorting many of the samples, P. Bonham for sorting and species identification, and S. E. Wayte for statistical advice. We thank. J. M. Leis and P. C. Rothlisberg for reviewing the manuscript and suggesting many improvements.

\section{LITERATURE CITED}

Ahlstrom, E. H. (1954). Distribution and abundance of egg and larval populations of the Pacific sardine. Fish. Bull. U.S. 56: 83-140

Ahlstrom, E. H. (1959). Vertical distribution of pelagic fish eggs and larvae off California and Baja California. Fish. Bull. U.S. 60: 107-146

Andrew, N. L., Mapstone, B. D. (1987). Sampling and the description of spatial pattern in marine ecology. Oceanogr. mar. Biol. A. Rev. 25: 39-90

Angel, M. V. (1968). The thermocline as an ecological boundary. Sarsia 34: 299-312

Badcock, J., Merrett, N. R. (1976). Midwater fishes in the eastern North Atlantic-I. Vertical distribution and associated biology in $30^{\circ} \mathrm{N}, 23^{\circ} \mathrm{W}$, with developmental notes on certain myctophids. Prog. Oceanogr 7:3-58

Barkley, R. A. (1972). Selectivity of towed-net samplers. Fish. Bull. U.S. 70: 799-820

Boehlert, G. W., Gadomski, D. M., Mundy, B. C. (1985). Vertical distribution of ichthyoplankton off the Oregon coast in spring and summer months. Fish. Bull. U.S. 83: 611-622

Brewer, G. D., Kleppel, G. S. (1986). Diel vertical distribution of fish larvae and their prey in nearshore waters of southern California. Mar. Ecol. Prog. Ser 27: 217-226

Brewer, G. D., Kleppel, G. S., Dempsey, M. (1984). Apparent predation on ichthyoplankton by zooplankton and fishes in nearshore waters of southern California. Mar. Biol. 80; $17-28$

Bridger, J. P. (1956). On day and night variation in catches of fish larvae. J. Cons. int. Explor. Mer 22; 42-57

Conand, F., Richards, W. J. (1982). Distribution of tuna larvae between Madagascar and the Equator, Indian Ocean. Biol. Oceanogr. 1: 321-336

Clutter, R. I., Anraku, M. (1968). Avoidance in samplers. In: Tranter, D. J. (ed.) Zooplankton sampling. UNESCO Press, Paris, p. 57-76

Cresswell, G. R., Richardson, G. T., Wood, J. E., Watts, R (1978). The CSIRO satellite-tracked 'torpedo' buoy. CSIRO Aust. Div. Fish. Oceanogr Rep. 82: 1-13

Dahlen, J. M. (1986). The Draper LCD a calibrated, low cost Lagrangian drifter The Charles Stark Draper Laboratory, Cambridge, MA, p, 1-14

Davis, T L. O., Clementson, L. A. (1989). Data report on the vertical and horizontal distribution of tuna larvae in the East Indian Ocean, January-February 1987. CSIRO Mar. Lab. Rep. 206

Davis, T L. O., Jenkins, G. P., Yukinawa, M., Nishikawa, Y. (1989). Tuna larvae abundance: comparative estimates from concurrent Japanese and Australian sampling programs. Fish. Bull. U.S. 87: (in press)

Fortier, L., Leggett, W. C. (1982). Fickian transport and the dispersal of fish larvae in estuaries. Can. J. Fish. Aquat. Sci. 39: 1150-1163

Gehringer, J. W. Aron, W. (1968). Field techniques. In: Tranter, D. J. (ed.) Zooplankton sampling. UNESCO Press Paris, p. 87-104

Hunter, J. R., Sanchez, C. (1976). Diel changes in swim bladder inflation of the larvae of the northern anchovy, Engraulis mordax. Fish. Bull. U.S. 74: 847-855

Kendall, A. W., Naplin, N. A. (1981). Diel-depth distribution of summer ichthyoplankton in the Middle Atlantic Bight. Fish. Bull. U.S. 79: 705-726

Kendall, M. G., Stuart, A. (1958). The advanced theory of statistics, Vol. 1. Distributional theory. Charles Griffin, London

Klawe, W. T. (1963). Observations of the spawning of four species of tuna (Neothunnus macropterus, Katsuwonus pelamis, Auxis thazard and Euthynnus lineatus) in the eastern Pacific Ocean, based on the distribution of their larvae and juveniles. Bull. inter-Am. trop. Tuna Commn. $6(9): 449-540$

Loeb, V. J. (1979). Vertical distribution and development of larval fishes in the North Pacific gyre during summer. Fish Bull. U.S. 77: 777-793

Matsumoto, W. M. (1958). Description and distribution of larvae of four species of tuna in Central Pacific Waters Fish. Bull. U.S. 58: 31-78

Miller, J. M. (1979). Nearshore abundance of tuna (Pisces Scombridae) larvae in the Hawaitan Islands. Bull. mar. Sci 29 (1): $19-26$ 
Murphy, G. I., Clutter, R. I. (1972). Sampling anchovy larvae with a plankton purse seine. Fish. Bull. U.S. 70: 789-798

Nakamura, E. L., Matsumoto, W M. (1965). Distribution of larval tunas in Marquesan waters. Fish. Bull. U.S. 66: 1-12

Nishikawa, Y. (1985). Identification for larvae of three species of genus Thunnus by melanophore patterns. Bull. Far Seas Fish. Res. Lab., Shimizu 22: 119-130

Nishikawa, Y., Honma, M., Ueyanagi, S., Kikawa, S. (1985). Average distribution of larvae of oceanic species of scombrid fishes, 1956-1981. Far Seas Fish. Res. Lab. S Ser 12 : $1-99$

Richards, W. J. (1969). Distribution and relative apparent abundance of larval tunas collected in the Tropical Atlantic during Equalant surveys I and II. Proceedings of the Symposium on the Oceanography and Fisheries Resources of the Tropical Atlantic - Review Papers and Contributions UNESCO Press, Paris, p. 289-315

Richards, W. J., Simmons, D. C. (1971). Distribution of tuna larvae (Pisces, Scombridae) in the northwestern Gulf of Guinea and off Sierra Leone. Fish. Bull. U.S. 69: 555-568

Seliverstov, A. S. (1974). Vertical migrations of larvae of the Atlanto-Scandian herring (Clupea harengus L.). In: Blaxter, J. H. S. (ed.) The early life history of fish. SpringerVerlag, Berlin, p. 253-262

Sogard, S. M., Hoss, D. E., Govoni, J. J. (1987). Density and depth distribution of larval gulf menhaden, Brevoortia patronus, Atlantic croaker, Micropogonias undulatus, and spot, Leiostomus xanthurus, in the northern Gulf of Mexico. Fish. Bull. U.S. 85: 601-609

Sokal, R. R., Rohlf, F. J. (1981). Biometry, 2nd edn. W $H$. Freeman, New York

Strasburg, D. W. (1960). Estimates of larval tuna abundance in the Central Pacific. Fish. Bull. U.S. 60: 231-255

Tranter, D. J., Smith, P. E. (1968). Filtration performance. In Tranter, D. J. (ed.) Zooplankton sampling. UNESCO Press, Paris, p. $27-56$

Ueyanagi, S. (1969). Observations on the distribution of tuna larvae in the Indo-Pacific Ocean with emphasis on the delineation of the spawning areas of the albacore, Thun-

This article was submitted to the editor nus alalunga. Bull. Far Seas Fish. Res. Lab., Shimizu 2: $177-254$

Uotani, I., Matsuzaki, K., Makino, Y., Noda, K., Inamura, O., Horikawa, M. (1981). Food habits of larvae of tunas and their related species in the area northwest of Australia. Bull. Jap. Soc. scient. Fish. 47: 1165-1172

Wade, C. B. (1951). Larvae of tuna and tuna-like fishes from Philippine waters. Fish. Bull. U.S. 51. 445-485

Winer, B. J. (1971). Statistical principles in experimental design, 2nd edn. McGraw-Hill, New York

Yabe, H., Ueyanagi, S., Watanabe, H. (1966). Studies on the early life history of bluefin tuna Thunnus thynnus and on the larva of the southern bluefin tuna $T$. maccoyii. Rep. Nankai Reg. Fish. Res. Lab. 23: 95-116

Yamashita, Y., Kitagawa, D., Aoyama, T (1985). Diel vertical migration and feeding rhythm of the larvae of the Japanese sand-eel, Ammodytes personatus. Bull. Jap. Soc. scient. Fish. 51: 1-5

Yonemori, T., Morita, J. (1978). Report on 1977 research cruise of the R $/$ Shoyo-Maru. Distribution of tuna and billfishes, and their larvae in the eastern Indian Ocean, OctoberDecember, 1977. Rep. Res. Div., Fish. Agency Jpn 52: 1-48

Yukinawa, M. (1987). Report on 1986 research cruise of the RV Shoyo-Maru. Distribution of tunas and billfishes larvae and oceanographic observation in the eastern Indian Ocean January-March, 1987. Rep. Res. Div., Fish. Agency Jpn 61. 1-100

Yukinawa, M. Koido, T. (1985). Report on 1984 research cruise of the R/V Shoyo-Maru third cruise. Distribution of tunas and billfishes and their larvae in the eastern Indian Ocean January-March, 1985. Rep. Res. Div., Fish. Agency Jpn 59: 1-108

Yukinawa, M., Miyabe, N. (1984). Report on 1983 research cruise of the R/V Shoyo-Maru. Distribution of tunas and billfishes and their larvae in the eastern Indian Ocean October-December, 1983. Rep. Res. Div., Fish. Agency Jpn 58: 1-103

Zar, J. H. (1984). Biostatistical analysis, 2nd edn. PrenticeHall, Englewood Cliffs, NJ

Manuscript first received: May 23, 1989

Revised version accepted: September 15, 1989 